\title{
Decreasing methane emission of rice by better crop management
}

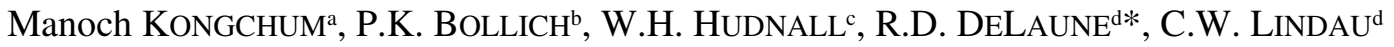 \\ ${ }^{a}$ Department of Agronomy and Environmental Management, Louisiana State University Baton Rouge, LA 70803, USA \\ ${ }^{\mathrm{b}}$ Louisiana State University Agricultural Center, Central Research Station, 2310 Ben Hur Road, Baton Rouge, LA 70820, USA \\ ${ }^{\mathrm{c}}$ Department of Plant and Soil Science, Texas Tech University, Lubbock, TX 79409, USA \\ ${ }^{\mathrm{d}}$ Wetland Biogeochemistry Institute, Louisiana State University, Baton Rouge, LA 70803, USA
}

(Accepted 1st September 2005)

\begin{abstract}
A field experiment was conducted to determine the effect of water management techniques for maintaining rice production and reducing methane emission in a Crowley silt loam paddy soil receiving high rice straw additions. A $2 \times 5$ factorial experiment was arranged in a split-plot design with two water management practices; alternately flooded and drained and continuously flooded, and five rates of rice straw incorporation as subplot treatments $\left(0,3,6,12\right.$ and $\left.24 \mathrm{t} \mathrm{ha}^{-1}\right)$, with four replications. Rice yield was significantly greater in the alternately flooded and drained treatment as compared with the continuously flooded treatment. High rice straw application $\left(12\right.$ and $\left.^{24} \mathrm{tha}^{-1}\right)$ reduced rice $^{-1}$ yield in both water management treatments. Methane emission increased with increase in the rice straw application rate. However, emissions were lower in the alternately flooded and drained treatment plots. The results demonstrate that draining a field for a short period of time during the growing season can enhance rice growth and rice yield while reducing methane emission.
\end{abstract}

paddy rice / water management / plant residue / methane emission / rice production

\section{INTRODUCTION}

According to world rice statistics (IRRI, 2002), the global rice harvested area was 147 million hectares in 2002, with a total rough rice production of 576 million tons. These numbers were approximately $3 \%$ less as compared with 2001. Globally irrigated rice is grown on about $50 \%$ of the total harvested rice area, contributing about $70 \%$ of total rice production.

Flooded rice fields are significant sources of atmospheric methane emission, which contribute to global warming (Neue, 1993; Neue et al., 1994). Methane is reported to account for 20 percent of global warming (Sass, 2003). Cultural practices such as added organic matter amendment (green manure) and plant residue from the previous rice crop effect methane emissions from rice (Schutz et al., 1989; Sass et al., 1991a, b; Wassmann, 1993). Organic matter dynamics, soil properties and rice cultural practices including water management are important factors governing the amount of methane emitted from flooded rice systems (Fig. 1) (Neue et al., 1990; Sass et al., 1992, 1994; Yagi et al., 1996; Wassmann et al., 2000; Neue, 1997).

Rice in the United States is grown under either water- or dryseeded cultural systems in Louisiana, Arkansas, Texas, Mississippi, Missouri and Florida (Linscombe et al., 1999; Miller and Street, 1999). California rice is cultured almost exclusively by water seeding. In Louisiana, water seeding is predominant but dry seeding also contributes significantly to total produc- tion, especially in the northeastern region of the state (Street and Bollich, 2003).

Three basic water management practices are used in both rice seeding systems in the US: (1) delayed flooding, (2) pinpoint flooding, and (3) continuous flooding (Street and Bollich, 2003). When a delayed flood is used, fields are drained after water seeding (usually 3 to 4 weeks) before the permanent flood is applied. This system is normally used where red rice is not a problem (Linscombe et al., 1999). Pinpoint flood is the most common practice used in the water seeding system. After seeding with presprouted seed, the field is drained briefly. This allows time for the radicle root to penetrate the soil and anchor the seedling. Under normal conditions, a three- to five-day drainage period is sufficient. The field is then permanently flooded until the rice is near maturity (Fig. 1). Since the field is maintained in a flooded (or saturated) condition, the oxygen necessary for red rice germination is lacking (Linscombe et al., 1999). Continuous flooding is used on a limited basis in Louisiana. This system is similar to the pinpoint system, except that after seeding, the field is never drained. Of the three water management systems, continuous flooding is normally best for red rice suppression, but stand establishment can be affected. Continuous flooding also provides excellent weed control, especially when coupled with herbicides (Hill et al., 1992).

Water management can also be used to mitigate $\mathrm{CH}_{4}$ emission from rice fields. Aeration of the soil by stopping irrigation or draining temporarily would enhance $\mathrm{CH}_{4}$ oxidation and

* Corresponding author: rdelaune@aol.com 


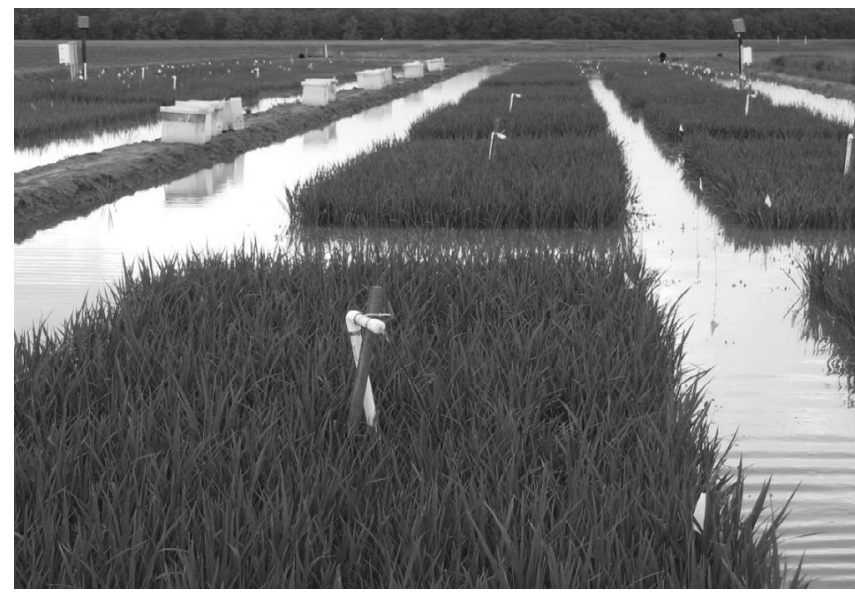

Figure 1. Rice experimental plots at Louisiana rice experimental station.

decrease $\mathrm{CH}_{4}$ production, resulting in lower methane emissions to the atmosphere (Wassmann et al., 2000; Lu et al., 2000). The use of a combination of mitigation technologies could reduce $\mathrm{CH}_{4}$ emission from rice fields without dramatically changing cultural practices or reducing rice yield.

Ponnamperuma (1984) reported rice straw incorporation generally resulted in higher rice grain yield than straw removal or burning, especially if rice straw incorporation continued for a number of growing seasons. The benefit is greater in warmer climates, where toxic compounds released by decomposition of incorporated straw had time to decompose before planting (Cho and Ponnamperuma, 1971). However, Gao et al. (2004) showed high rates of rice straw incorporation adversely affected rice growth and grain yield.

Rice plants can enhance $\mathrm{CH}_{4}$ production and flux by providing organic substrates for methanogenic bacteria through the production of root litter and root exudates (HolzapfelPschorn et al., 1986; Sass et al., 1990). Sass et al. (1990) and Whiting et al. (1991) reported a linear relationship between plant biomass and $\mathrm{CH}_{4}$ emissions. Wang et al. (1992) also found a positive correlation between $\mathrm{CH}_{4}$ emission rate and straw application rate in Crowley soil up to a rate of $20 \mathrm{~g} \mathrm{~kg}^{-1}$ $\left(44 \mathrm{t} \mathrm{ha}^{-1}\right)$. However, Kludze and DeLaune (1995) concluded that the $\mathrm{CH}_{4}$ emission rate did not always show a positive correlation to the straw application rate.

The emission of methane from the rice field is also affected by other soil physical and chemical properties. Soil properties include nitrogen content, cation exchange capacity, amount and form of $\mathrm{Fe}$ and $\mathrm{Mn}$ in the soil solution, soil redox potential, soil pH and soil texture (Wang et al., 1992; Lindau et al., 1993). The objective of this field experiment was to evaluate water management techniques for both maintaining rice yield and reducing methane emission in Crowley soil receiving high organic matter in the form of rice straw.

\section{MATERIALS AND METHODS}

The experiment was conducted at the Rice Research Station, Crowley, Louisiana. The soil was classified as a Crowley silt loam (Typic Albaqualf) containing $7.0 \mathrm{~g}$ total $\mathrm{C} \mathrm{kg}^{-1}$ and $0.80 \mathrm{~g}$ total $\mathrm{N} \mathrm{kg}^{-1}$ soil. Soil $\mathrm{pH}$ was 6.2 (1.1 soil/water) and cation exchange capacity was $9.4 \mathrm{cmol} \mathrm{kg}^{-1}$ soil. The silt loam contained $710 \mathrm{~g}$ silt kg$^{-1}$ and $120 \mathrm{~g}$ clay kg $^{-1}$ soil (Tab. I). A $2 \times$ 5 factorial experiment was arranged in a split-plot design with two water management practices as main plot treatments (alternately flooded and drained and continuously flooded) and five rates of rice straw incorporation as subplot treatments $(0,3,6$, 12 and $24 \mathrm{t} \mathrm{ha}^{-1}$ ), with four replications. Plots size was $2.1 \times$ $6 \mathrm{~m}$.

Nitrogen, $\mathrm{P}$ and $\mathrm{K}$ were applied to the soil at a rate of 100$75-75 \mathrm{~kg} \mathrm{ha}^{-1}$, respectively, as pre-plant incorporation and the second nitrogen application $\left(85 \mathrm{~kg} \mathrm{ha}^{-1}\right)$ was applied six weeks after planting. Rice straw was incorporated to a soil depth of $15 \mathrm{~cm}$ at assigned rates using a rotary tiller. Four platinum electrodes were placed in all plots at a depth of $10 \mathrm{~cm}$. A pH electrode was placed in one replication of each water management main plot. Soil redox potential and $\mathrm{pH}$ data were recorded hourly in established plots via data loggers until harvest.

Rice straw was incorporated on April 2, 2003, plots were planted (wet-seeded) at a seed rate of $150 \mathrm{~kg} \mathrm{ha}^{-1}$ with rice (variety Cocodrie) on April 16, pinpoint drain occurred on April 20 and permanent flood was established on April 25. The alternately flooded and drained treatment plots were drained on May 19 and reflooded on May 29 with the second nitrogen application. Continuously flooded and alternately flooded and drained treatment plots were permanently drained on July 25 and July 29, respectively, prior to harvest on August 4, 2003.

\subsection{Plant growth measurement}

A plot area of 0.5 square meters was marked for observation of plant growth, plant sampling and grain yield measurement.

Table I. Procedures used for soil analysis.

\begin{tabular}{|c|c|c|}
\hline Soil Properties & Procedures & References \\
\hline Organic matter & $1 \mathrm{M} \mathrm{K}_{2} \mathrm{Cr}_{2} \mathrm{O}_{7}+$ Conc. $\mathrm{H}_{2} \mathrm{SO}_{4}$, Colorimeter & Nelson and Sommers, 1982 \\
\hline $\mathrm{pH}$ & 1:1 (soil weight: DIW volume) & McLean, 1982 \\
\hline Available P & $0.03 \mathrm{M} \mathrm{NH}_{4} \mathrm{~F}$ and $0.1 \mathrm{M} \mathrm{HCl}, \mathrm{ICP}$ & Bray and Kurtz, 1945 \\
\hline Extractable $\mathrm{K}, \mathrm{Ca}, \mathrm{Mg}, \mathrm{Na}$ & $1 \mathrm{M} \mathrm{NH}_{4} \mathrm{OAc} \mathrm{pH} 7.0, \mathrm{ICP}$ & Thomas, 1982 \\
\hline Sulfur & $0.5 \mathrm{M} \mathrm{NH}_{4} \mathrm{OAc}$ and $0.25 \mathrm{M} \mathrm{HOAc}, \mathrm{ICP}$ & Tabatabai, 1982 \\
\hline Iron, Manganese, Zinc & 0.005M DTPA, pH 7.3, ICP & Lindsay and Norvell, 1978 \\
\hline Particle Size & Pipette method & Soil Survey Laboratory Methods Manual, 1996 \\
\hline
\end{tabular}


Plant height and stem number were recorded at 17, 33, 50, 64 and 110 days after planting. Plant samples were clipped and collected at maturity from a 0.5 -square-meter section of the plot. The samples were measured for height, and weighed after drying at $65-70{ }^{\circ} \mathrm{C}$ in an oven for 72 hours. Stem dry weight and grain yield were recorded. Plant stems and grain were randomly sub-sampled and ground for nutrient analysis.

\subsection{Soil sampling and analysis}

Soil samples were collected at harvest from all treatment plots using a five-cm diameter plastic tube. The tube was placed on the soil surface and inserted to a depth of $15 \mathrm{~cm}$. Collected soil samples were air-dried and analyzed for $\mathrm{pH}$, organic carbon, $\mathrm{S}, \mathrm{P}, \mathrm{K}, \mathrm{Ca}, \mathrm{Mg}$, $\mathrm{Na}$ and $\mathrm{Fe}$ using the methods outlined in Table I.

\subsection{Methane flux measurement}

Methane emissions were measured using diffusion chambers (Lindau et al., 1991) placed within the treatment plots. Chambers consisted of permanently installed base units $(30 \mathrm{~cm} \times 30 \mathrm{~cm} \times 30 \mathrm{~cm})$ and clean removable tops $(30 \mathrm{~cm} \times$ $30 \mathrm{~cm} \times 30 \mathrm{~cm})$ to prevent leaf damage; the base units were stacked as the rice grew. A $15-\mathrm{mL}$ gas sample was withdrawn from the chamber using a 20 -mL gas-tight syringe at 0 and 15 minute after placement of the diffusion chamber on the base unit. Sampling times were determined from a preliminary study to determine the linear rate of methane build-up in the chamber headspace, assuming no interference by ebullition of methane. Gas samples were collected at 2, 9, 17, 33, 40, 50, 64, 79 and 99 days after planting or 18 April 03, 25 April 03, 3 May 03, 19 May 03, 26 May 03, 5 June 03, 19 June 03, 4 July 03 and 24 July 03, respectively. Collected samples were injected into $10-\mathrm{mL}$ glass vacutainers. Prior to collection, the vacutainers were evacuated using a high-vacuum preparation line to remove residual gases (Lindau et al., 1991). Once evacuated, the tubes were sealed with silicone rubber and subsequently resealed after injecting of the sample. Floodwater heights and air temperatures inside the chambers were recorded for calculation of headspace volume and methane emission rate.

Gas samples were analyzed for methane using a Shimadzu GC14-A flame ionization gas chromatograph. A gas-tight syringe was used to inject a $1.0-\mathrm{mL}$ gas sample into a stainless steel column $(0.003 \times 2.4 \mathrm{~m})$ packed with Haye Sep O polymer (100/200 mesh). Column temperature was $40^{\circ} \mathrm{C}$ and injection and detection set at 100 and $200{ }^{\circ} \mathrm{C}$, respectively. Integration and analysis were accomplished with the use of a Shimadzu R-14AC Chromatopac. Raw data were recorded and used to calculate the flux of $\mathrm{CH}_{4}$ per unit area. A closed chamber equation (Rolston, 1986) was used to estimate methane fluxes from each treatment.

\subsection{Statistical analysis}

Data were analyzed by IRRISTAT software (IRRI, 1992). If any results from ANOVA showed significance, then mean comparisons were obtained with Duncan's Multiple Range Test.

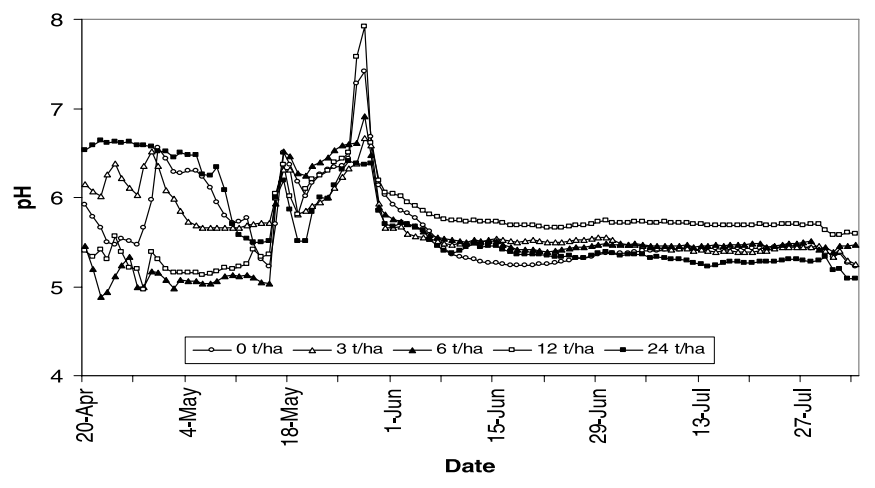

Figure 2. Effect of rice straw and water management practices on soil $\mathrm{pH}$ in the alternately flooded and drained treatment. 0 (control), 3, 6, 12 and $24=$ rice straw incorporation rates $\left(\mathrm{t} \mathrm{ha}^{-1}\right)$.

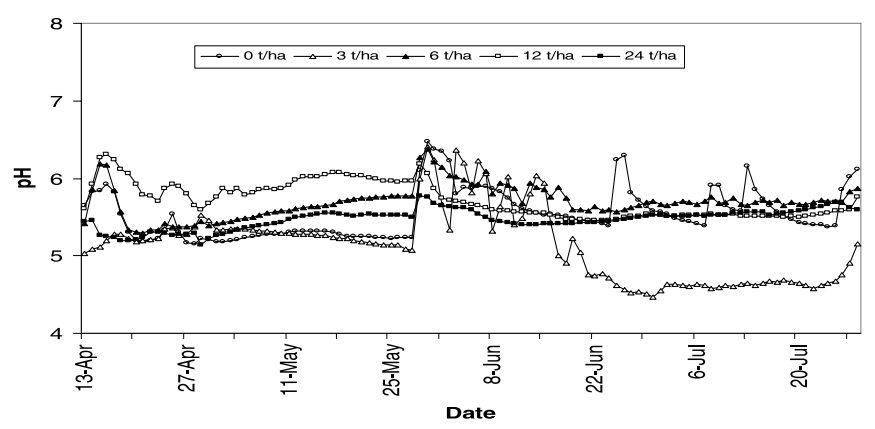

Figure 3. Effect of rice straw and water management practices on soil $\mathrm{pH}$ in the continuously flooded treatment. 0 (control), 3, 6, 12 and $24=$ rice straw incorporation rates $\left(\mathrm{t} \mathrm{ha}^{-1}\right)$.

\section{RESULTS AND DISCUSSION}

\subsection{Soil pH and Eh}

In the alternately flooded and drained treatment, soil $\mathrm{pH}$ ranged between 4.9 and 6.6 during the first week (20 April to 22 April 03) after planting (Fig. 2). During the draining period (19-29 May 03), soil $\mathrm{pH}$ increased from 6.0 to 8.0. After reflooding, soil $\mathrm{pH}$ decreased with less fluctuation, ranging between 5.3 and 5.7. Average soil $\mathrm{pH}$ of the alternately flooded and drained treatments was higher at the higher rate of straw addition. With the continuously flooded treatment, soil $\mathrm{pH}$ during the first week (5.2-6.3) fluctuated less compared with the alternately flooded and drained treatment (Fig. 3). The maximum $\mathrm{pH}$ value was measured in treatments that received straw at a rate of $12 \mathrm{t} \mathrm{ha}^{-1}$. The $\mathrm{pH}$ fluctuated widely between midseason and harvest.

Soil redox potential in the alternately flooded drained treatment was inversely correlated with rice straw application rate (Fig. 4). The treatment with a higher rate of straw addition had a lower Eh value than treatments with lower levels of added rice straw. During the drainage period, soil Eh increased significantly in all organic matter application levels. In the continuously flooded treatment, soil redox was also inversely related to application of rice straw. Soil Eh again decreased after reflooding (averaged over the entire growing season, soil Eh 


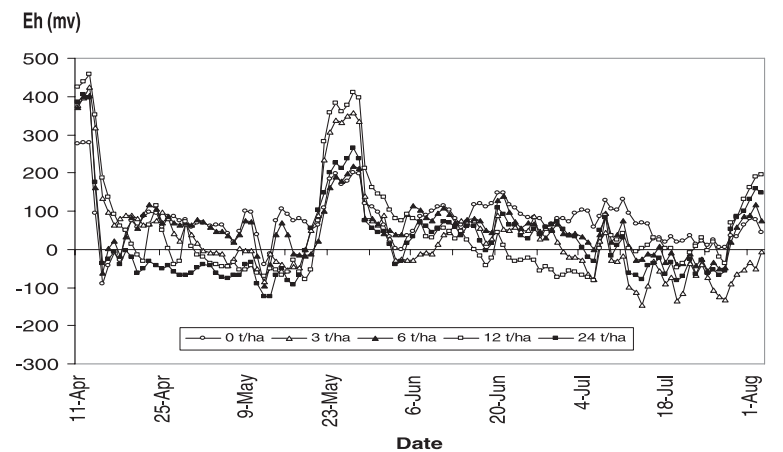

Figure 4. Effect of rice straw and water management practices on soil redox potential in the alternately flooded and drained treatment. 0 (control), 3, 6, 12 and $24=$ rice straw incorporation rates $\left(\mathrm{t} \mathrm{ha}^{-1}\right)$.

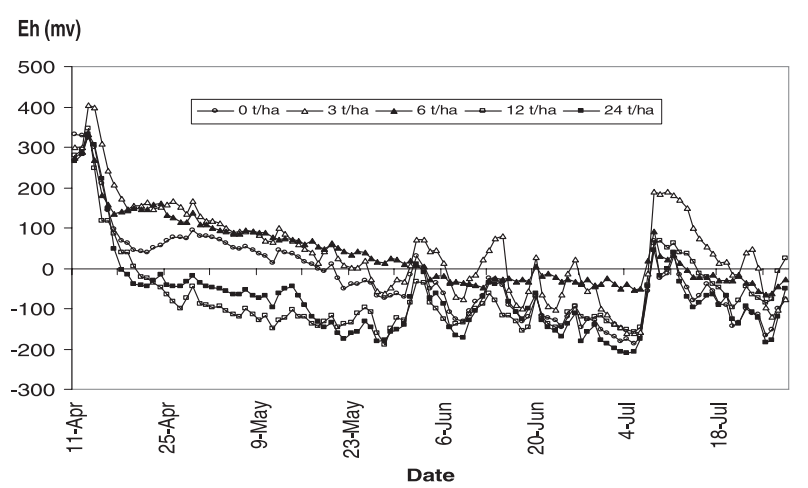

Figure 5. Effect of rice straw and water management practices on soil redox potential in the continuously flooded treatment. 0 (control), 3 , 6,12 and $24=$ rice straw incorporation rates $\left(\mathrm{t} \mathrm{ha}^{-1}\right)$.

was in the range of +100 to $+400 \mathrm{mV}$ during the draining period). In addition, the measured Eh value could be separated into two distinct ranges for the first half of the season. The first range comprises values above $0 \mathrm{mV}$. The second range of Eh values was below $0 \mathrm{mV}$ and associated with application rates of 12 and $24 \mathrm{t} \mathrm{ha}^{-1}$ (Fig. 5). Average Eh values in the continuously flooded treatment decreased with time followed by some increases at the end of the season. This was attributed to water leaking from the main plot.

\subsection{Soil properties}

Average soil $\mathrm{pH}$ (7.12) of the alternately flooded and drained treatment (control -0 t ha $^{-1}$ ) was slightly higher compared with the continuously flooded treatment (6.70). Soil pHs for higher straw applications $\left(6,12\right.$ and $\left.24 \mathrm{tha}^{-1}\right)$ in the alternately flooded and drained treatment were significantly more acidic than control treatments, but there were no statistical differences in the continuously flooded treatment (Tab. II). Measured soil organic matter level was related to the straw application rate. The highest contents of soil organic matter were in the treatment receiving $24 \mathrm{tha}^{-1}$ of rice straw. The lowest soil organic matter level was in the treatment which received no added rice straw (control plots). Water management treatment had no effect on soil organic matter content. The amount of extractable sulfur in soil of the continuously flooded treatment was related to both amounts of rice straw addition $(P<0.01)$ and water management $(P<0.05)$ treatments. In the continuously flooded treatment, extractable sulfur decreased with an increasing rate of rice straw application. However, the differences in extractable sulfur in the alternately flooded and drained treatment were not significant.

Available phosphorus levels were not significantly different for any level of rice straw application, but levels were significantly greater in the continuously flooded treatment compared with the alternately flooded and drained treatment. Extractable soil potassium content for the higher straw application rate was significantly greater than in lower straw applications $(P<0.05)$. Soil potassium content was also significantly greater in the continuously flooded treatment than in the alternately flooded and drained treatment (Tab. II).

\subsection{Nutrient content in rice tissue}

Plant stem content of nitrogen at harvest was slightly greater with higher rice straw application rates compared with the lower rice straw application rates for both water management treatments, but the difference was not significant (Tab. III). The stem content of nitrogen in the alternately flooded and drained treatment $(0.64 \%)$ was significantly greater $(P<0.01)$ than the continuously flooded treatment $(0.56 \%)$. Water management treatments had no influence on the amount of stem content of

Table II. Effect of rice straw and water management treatments on selected soil properties. AFD = alternately flooded and drained treatment, $\mathrm{CF}=$ continuously flooded treatment.

\begin{tabular}{|c|c|c|c|c|c|c|c|c|c|c|}
\hline \multirow{2}{*}{$\begin{array}{l}\text { Rice straw } \\
\text { (t/ha) }\end{array}$} & \multicolumn{2}{|c|}{ Soil pH (1:1) } & \multicolumn{2}{|c|}{ Soil O.M. (\%) } & \multicolumn{2}{|c|}{ Extractable S (ppm) } & \multicolumn{2}{|c|}{ Available P (ppm) } & \multicolumn{2}{|c|}{ Exchangeable K (ppm) } \\
\hline & AFD & $\mathrm{CF}$ & AFD & $\mathrm{CF}$ & AFD & $\mathrm{CF}$ & AFD & $\mathrm{CF}$ & AFD & $\mathrm{CF}$ \\
\hline 0 & $7.12^{\mathrm{a}}$ & $6.70^{\mathrm{ab}}$ & $1.18^{\mathrm{c}}$ & $1.21^{\mathrm{d}}$ & $19.5^{\mathrm{a}}$ & $17.7^{\mathrm{bc}}$ & $48.5^{\mathrm{a}}$ & $58.3^{\mathrm{a}}$ & $50^{\mathrm{b}}$ & $65^{\mathrm{d}}$ \\
\hline 3 & $6.83^{\mathrm{ab}}$ & $6.87^{\mathrm{ab}}$ & $1.33^{\mathrm{bc}}$ & $1.28^{\mathrm{cd}}$ & $18.7^{\mathrm{a}}$ & $19.7^{\mathrm{a}}$ & $40.5^{\mathrm{a}}$ & $54.3^{\mathrm{a}}$ & $51^{\mathrm{b}}$ & $81^{\mathrm{c}}$ \\
\hline 6 & $6.75^{\mathrm{b}}$ & $6.71^{\mathrm{ab}}$ & $1.35^{\mathrm{b}}$ & $1.37^{\mathrm{bc}}$ & $19.0^{\mathrm{a}}$ & $19.2^{\mathrm{a}}$ & $46.0^{\mathrm{a}}$ & $55.3^{\mathrm{a}}$ & $62^{\mathrm{b}}$ & $94^{\mathrm{c}}$ \\
\hline 12 & $6.50^{\mathrm{b}}$ & $6.67^{\mathrm{ab}}$ & $1.38^{\mathrm{b}}$ & $1.51^{\mathrm{b}}$ & $18.3^{\mathrm{a}}$ & $18.7^{\mathrm{ab}}$ & $41.3^{\mathrm{a}}$ & $55.0^{\mathrm{a}}$ & $64^{\mathrm{b}}$ & $118^{\mathrm{b}}$ \\
\hline 24 & $6.48^{\mathrm{b}}$ & $6.48^{\mathrm{b}}$ & $1.73^{\mathrm{a}}$ & $1.72^{\mathrm{a}}$ & $19.1^{\mathrm{a}}$ & $16.6^{\mathrm{c}}$ & $50.8^{\mathrm{a}}$ & $60.3^{\mathrm{a}}$ & $153^{\mathrm{a}}$ & $151^{\mathrm{a}}$ \\
\hline Water mean & 6.74 & 6.69 & 1.39 & 1.42 & 18.9 & 18.4 & 45.4 & 56.6 & 76 & 102 \\
\hline $\mathrm{CV} / \mathrm{F}$-test & Water & $4.7 \mathrm{~ns}$ & & $17.7 \mathrm{~ns}$ & & $4.9^{*}$ & & $11.6^{* *}$ & & $5.2^{* *}$ \\
\hline $\mathrm{CV} / \mathrm{F}$-test & Rice straw & $3.5^{* *}$ & & $7.7 * *$ & & $5.2 * *$ & & $15.8 \mathrm{~ns}$ & & $12.1 * *$ \\
\hline
\end{tabular}

Average of four replications. In each column, means followed by a common letter are not significantly different at the 5\% level; ns $=$ not significant, $*$ = significant at $5 \%$ level, $* *=$ significant at $1 \%$ level. 
Table III. Effect of rice straw and water management treatments on nutrient content (\%) in rice stems. AFD = alternately flooded and drained treatment, $\mathrm{CF}=$ continuously flooded treatment.

\begin{tabular}{|c|c|c|c|c|c|c|c|c|c|c|}
\hline \multirow{2}{*}{$\begin{array}{l}\text { Rice straw } \\
(\mathrm{t} / \mathrm{ha})\end{array}$} & \multicolumn{2}{|c|}{ Total N (\%) } & \multicolumn{2}{|c|}{ Total P (\%) } & \multicolumn{2}{|c|}{ Total K (\%) } & \multicolumn{2}{|c|}{ Total S (\%) } & \multicolumn{2}{|c|}{ Total Ca $(\%)$} \\
\hline & AFD & $\mathrm{CF}$ & AFD & $\mathrm{CF}$ & AFD & $\mathrm{CF}$ & AFD & $\mathrm{CF}$ & AFD & $\mathrm{CF}$ \\
\hline 0 & $0.59^{\mathrm{a}}$ & $0.53^{\mathrm{a}}$ & $0.09^{\mathrm{a}}$ & $0.06^{\mathrm{c}}$ & $1.17^{\mathrm{a}}$ & $1.10^{\mathrm{c}}$ & $0.06^{\mathrm{a}}$ & $0.06^{\mathrm{a}}$ & $0.35^{\mathrm{a}}$ & $0.35^{\mathrm{a}}$ \\
\hline 3 & $0.61^{\mathrm{a}}$ & $0.52^{\mathrm{a}}$ & $0.08^{\mathrm{a}}$ & $0.07^{\mathrm{bc}}$ & $1.34^{\mathrm{bc}}$ & $1.63^{\mathrm{ab}}$ & $0.06^{\mathrm{a}}$ & $0.06^{\mathrm{a}}$ & $0.33^{\mathrm{a}}$ & $0.29^{\mathrm{a}}$ \\
\hline 6 & $0.71^{\mathrm{a}}$ & $0.53^{\mathrm{a}}$ & $0.10^{\mathrm{a}}$ & $0.09^{\mathrm{b}}$ & $1.38^{\mathrm{abc}}$ & $1.55^{\mathrm{b}}$ & $0.07^{\mathrm{a}}$ & $0.05^{\mathrm{a}}$ & $0.34^{\mathrm{a}}$ & $0.29^{\mathrm{a}}$ \\
\hline 12 & $0.61^{\mathrm{a}}$ & $0.58^{\mathrm{a}}$ & $0.10^{\mathrm{a}}$ & $0.09^{\mathrm{b}}$ & $1.64^{\mathrm{ab}}$ & $1.51^{\mathrm{b}}$ & $0.06^{\mathrm{a}}$ & $0.06^{\mathrm{a}}$ & $0.27^{\mathrm{b}}$ & $0.30^{\mathrm{a}}$ \\
\hline 24 & $0.69^{\mathrm{a}}$ & $0.62^{\mathrm{a}}$ & $0.12^{\mathrm{a}}$ & $0.12^{\mathrm{a}}$ & $1.70^{\mathrm{a}}$ & $1.92^{\mathrm{a}}$ & $0.06^{\mathrm{a}}$ & $0.06^{\mathrm{a}}$ & $0.31^{\mathrm{ab}}$ & $0.23^{\mathrm{b}}$ \\
\hline Water mean & 0.64 & 0.56 & 0.10 & 0.09 & 1.45 & 1.54 & 0.06 & 0.06 & 0.32 & 0.29 \\
\hline $\mathrm{CV} / \mathrm{F}$-test & Water & $19.5^{* *}$ & & $15.2 \mathrm{~ns}$ & & $11.4 \mathrm{~ns}$ & & $13.9 \mathrm{~ns}$ & & $12.1 * *$ \\
\hline CV/F-test & Rice straw & $13.7 \mathrm{~ns}$ & & $19.9^{* *}$ & & $14.0^{* *}$ & & $10.7 \mathrm{~ns}$ & & $12.7 * *$ \\
\hline
\end{tabular}

Average of four replications. In each column, means followed by a common letter are not significantly different at the 5\% level; ns $=$ not significant,$*=$ significant at $5 \%$ level, $* *=$ significant at $1 \%$ level.

Table IV. Effect of rice straw and water management treatments on nutrient content (\%) in rice grain.

\begin{tabular}{|c|c|c|c|c|c|c|c|c|c|c|}
\hline \multirow{2}{*}{$\begin{array}{l}\text { Rice straw } \\
(\mathrm{t} / \mathrm{ha})\end{array}$} & \multicolumn{2}{|c|}{ Total N (\%) } & \multicolumn{2}{|c|}{ Total P (\%) } & \multicolumn{2}{|c|}{ Total K (\%) } & \multicolumn{2}{|c|}{ Total S (\%) } & \multicolumn{2}{|c|}{ Total Ca (\%) } \\
\hline & AFD & $\mathrm{CF}$ & AFD & $\mathrm{CF}$ & AFD & $\mathrm{CF}$ & AFD & $\mathrm{CF}$ & AFD & $\mathrm{CF}$ \\
\hline 0 & $1.05^{\mathrm{a}}$ & $0.93^{\mathrm{a}}$ & $0.3^{\mathrm{a}}$ & $0.28^{\mathrm{a}}$ & $0.34^{\mathrm{a}}$ & $0.31^{\mathrm{a}}$ & $0.080^{\mathrm{a}}$ & $0.068^{\mathrm{a}}$ & $0.05^{\mathrm{a}}$ & $0.05^{\mathrm{a}}$ \\
\hline 3 & $1.05^{\mathrm{a}}$ & $0.96^{\mathrm{a}}$ & $0.32^{\mathrm{a}}$ & $0.27^{\mathrm{a}}$ & $0.34^{\mathrm{a}}$ & $0.29^{\mathrm{a}}$ & $0.078^{\mathrm{a}}$ & $0.070^{\mathrm{a}}$ & $0.05^{\mathrm{a}}$ & $0.04^{\mathrm{a}}$ \\
\hline 6 & $1.04^{\mathrm{a}}$ & $1.01^{\mathrm{a}}$ & $0.32^{\mathrm{a}}$ & $0.31^{\mathrm{a}}$ & $0.37^{\mathrm{a}}$ & $0.32^{\mathrm{a}}$ & $0.073^{\mathrm{a}}$ & $0.070^{\mathrm{a}}$ & $0.05^{\mathrm{a}}$ & $0.05^{\mathrm{a}}$ \\
\hline 12 & $1.05^{\mathrm{a}}$ & $1.02^{\mathrm{a}}$ & $0.33^{\mathrm{a}}$ & $0.32^{\mathrm{a}}$ & $0.36^{\mathrm{a}}$ & $0.32^{\mathrm{a}}$ & $0.070^{\mathrm{a}}$ & $0.070^{\mathrm{a}}$ & $0.05^{\mathrm{a}}$ & $0.05^{\mathrm{a}}$ \\
\hline 24 & $1.04^{\mathrm{a}}$ & $1.07^{\mathrm{a}}$ & $0.30^{\mathrm{a}}$ & $0.32^{\mathrm{a}}$ & $0.36^{\mathrm{a}}$ & $0.35^{\mathrm{a}}$ & $0.073^{\mathrm{a}}$ & $0.078^{\mathrm{a}}$ & $0.05^{\mathrm{a}}$ & $0.05^{\mathrm{a}}$ \\
\hline Water mean & 1.05 & 1.00 & 0.31 & 0.30 & 0.35 & 0.32 & 0.075 & 0.071 & 0.05 & $0.05^{\mathrm{a}}$ \\
\hline CV/F-test & Water & $6.8^{*}$ & & $19.4 \mathrm{~ns}$ & & $23.9 \mathrm{~ns}$ & & $7.4 * *$ & & $1.4 \mathrm{~ns}$ \\
\hline $\mathrm{CV} / \mathrm{F}$-test & Rice straw & $4.1 \mathrm{~ns}$ & & $18.0 \mathrm{~ns}$ & & $19.5 \mathrm{~ns}$ & & $6.0 \mathrm{~ns}$ & & $25.5 \mathrm{~ns}$ \\
\hline
\end{tabular}

Average of four replications. In each column, means followed by a common letter are not significantly different at the 5\% level;

ns $=$ not significant,$*=$ significant at $5 \%$ level, $* *=$ significant at $1 \%$ level.

phosphorus or potassium. Significant differences in rice stem potassium content were observed among rice straw application rates.

Total stem content of sulfur was not significantly different among straw application rates and between water management treatments. Total stem content of calcium at the higher straw application rate $\left(24 \mathrm{t} \mathrm{ha}^{-1}\right)$ was significantly $(P<0.01)$ lower compared with the lower rates of straw application for the continuously flooded water treatment. The average stem content of calcium over straw application rates in the alternately flooded and drained treatment $(0.32 \%)$ was significantly greater $(P<0.01)$ than that observed in the continuously flooded treatment $(0.29 \%)$.

The average grain content of nitrogen was approximately $1.05 \%$ in the alternately flooded and drained treatment, and was significantly higher compared with $1.00 \%$ in the continuously flooded treatment (Tab. IV). Grain content of nitrogen for both water treatments was not significantly affected by straw application rates. Neither straw application nor water management treatments influenced grain content of phosphorus, potassium or calcium. Total grain content of sulfur in the alternately flooded and drained treatment $(0.075 \%)$ was significantly greater $(P<0.01)$ than the continuously flooded treatment
$(0.071 \%)$, but no significance differences were calculated among straw application rates.

\subsection{Nutrient uptake in the rice plant}

Nutrient uptake was calculated using plant dry weight and plant tissue concentration. Total stem nitrogen uptake was not different among rates of straw application for both water management treatments (Tab. V). The stem nitrogen uptake in the alternately flooded and drained treatment $\left(39.9 \mathrm{~kg} \mathrm{ha}^{-1}\right)$ was significantly greater $(P<0.01)$ compared with the continuously flooded treatment $\left(26.8 \mathrm{~kg} \mathrm{ha}^{-1}\right)$, but the difference was not significant with an increasing rate of straw addition. Uptake of both phosphorous and potassium was greater $(P<0.01)$ for the alternately flooded and drained treatment than for the continuously flooded treatment, and in most cases greater with an increasing rate of straw addition.

Grain nitrogen uptake was significantly greater at higher straw application rates $\left(12\right.$ and $\left.24 \mathrm{t} \mathrm{ha}^{-1}\right)$ compared with the lower rates $\left(0,3\right.$ and $\left.6 \mathrm{t} \mathrm{ha}^{-1}\right)$ for the continuously flooded treatment (Tab. VI). The alternately flooded and drained treatment $\left(148.9 \mathrm{~kg} \mathrm{ha}^{-1}\right)$ resulted in more grain nitrogen uptake than in the continuously flooded treatment $\left(100.5 \mathrm{~kg} \mathrm{ha}^{-1}\right)$. Average grain $\mathrm{P}$ uptake in the alternately flooded and drained treatment 
Table V. Effect of rice straw and water management treatments on nutrient uptake $\left(\mathrm{kg} \mathrm{ha}^{-1}\right)$ in rice stems at maturity. AFD $=$ alternately flooded and drained treatment, $\mathrm{CF}=$ continuously flooded treatment.

\begin{tabular}{|c|c|c|c|c|c|c|c|c|c|c|}
\hline \multirow{2}{*}{$\begin{array}{l}\text { Rice straw } \\
(\mathrm{t} / \mathrm{ha})\end{array}$} & \multicolumn{2}{|c|}{ Total $\mathrm{N}\left(\mathrm{kg} \mathrm{ha}^{-1}\right)$} & \multicolumn{2}{|c|}{ Total P $\left(\mathrm{kg} \mathrm{ha}^{-1}\right)$} & \multicolumn{2}{|c|}{ Total $\mathrm{K}\left(\mathrm{kg} \mathrm{ha}^{-1}\right)$} & \multicolumn{2}{|c|}{ Total S $\left(\mathrm{kg} \mathrm{ha}^{-1}\right)$} & \multicolumn{2}{|c|}{ Total Ca $\left(\mathrm{kg} \mathrm{ha}^{-1}\right)$} \\
\hline & AFD & $\mathrm{CF}$ & AFD & $\mathrm{CF}$ & AFD & $\mathrm{CF}$ & AFD & $\mathrm{CF}$ & AFD & $\mathrm{CF}$ \\
\hline 0 & $38.3^{\mathrm{a}}$ & $26.2^{\mathrm{a}}$ & $5.6^{\mathrm{ab}}$ & $2.9^{\mathrm{c}}$ & $75.7^{\mathrm{c}}$ & $54.6^{\mathrm{b}}$ & $4.2^{\mathrm{a}}$ & $2.8^{\mathrm{a}}$ & $22.8^{\mathrm{a}}$ & $17.0^{\mathrm{a}}$ \\
\hline 3 & $34.5^{\mathrm{a}}$ & $22.0^{\mathrm{a}}$ & $4.6^{\mathrm{b}}$ & $2.8^{\mathrm{c}}$ & $77.4^{\mathrm{c}}$ & $69.4^{\mathrm{ab}}$ & $3.5^{\mathrm{a}}$ & $2.4^{\mathrm{a}}$ & $19.2^{\mathrm{a}}$ & $12.0^{\mathrm{a}}$ \\
\hline 6 & $43.8^{\mathrm{a}}$ & $24.7^{\mathrm{a}}$ & $6.0^{\mathrm{ab}}$ & $4.1^{\mathrm{bc}}$ & $84.3^{\mathrm{bc}}$ & $72.8^{\mathrm{ab}}$ & $4.2^{\mathrm{a}}$ & $2.5^{\mathrm{a}}$ & $20.8^{\mathrm{a}}$ & $13.6^{\mathrm{a}}$ \\
\hline 12 & $38.1^{\mathrm{a}}$ & $31.1^{\mathrm{a}}$ & $6.3^{\mathrm{ab}}$ & $5.0^{\mathrm{ab}}$ & $103.3^{\mathrm{ab}}$ & $81.6^{\mathrm{a}}$ & $3.6^{\mathrm{a}}$ & $3.2^{\mathrm{a}}$ & $17.1^{\mathrm{a}}$ & $16.3^{\mathrm{a}}$ \\
\hline 24 & $44.6^{\mathrm{a}}$ & $29.9^{\mathrm{a}}$ & $7.0^{\mathrm{a}}$ & $6.0^{\mathrm{a}}$ & $109.2^{\mathrm{a}}$ & $92.9^{\mathrm{a}}$ & $4.0^{\mathrm{a}}$ & $2.9^{\mathrm{a}}$ & $20.4^{\mathrm{a}}$ & $11.2^{\mathrm{a}}$ \\
\hline Water mean & 39.9 & 26.8 & 5.9 & 4.2 & 90.0 & 74.3 & 3.9 & 2.8 & 20.1 & 14.0 \\
\hline CV/F-test & Water & $31.9 * *$ & & $32.1 * *$ & & $16.1 * *$ & & $23.5^{* *}$ & & $21.9 * *$ \\
\hline $\mathrm{CV} / \mathrm{F}$-test & Rice straw & $17.9 \mathrm{~ns}$ & & $23.2 * *$ & & $18.1 * *$ & & $15.2 \mathrm{~ns}$ & & $18.3 \mathrm{~ns}$ \\
\hline
\end{tabular}

Average of four replications. In each column, means followed by a common letter are not significantly different at the 5\% level; ns $=$ not significant,$*=$ significant at $5 \%$ level, $* *=$ significant at $1 \%$ level.

Table VI. Effect of rice straw and water management treatments on nutrient uptake in rice grain $\left(\mathrm{kg} \mathrm{ha}^{-1}\right)$.

\begin{tabular}{|c|c|c|c|c|c|c|c|c|c|c|}
\hline \multirow{2}{*}{$\begin{array}{l}\text { Rice straw } \\
(\mathrm{t} / \mathrm{ha})\end{array}$} & \multicolumn{2}{|c|}{ Total $\mathrm{N}\left(\mathrm{kg} \mathrm{ha}^{-1}\right)$} & \multicolumn{2}{|c|}{ Total $\mathrm{P}\left(\mathrm{kg} \mathrm{ha}^{-1}\right)$} & \multicolumn{2}{|c|}{ Total $\mathrm{K}\left(\mathrm{kg} \mathrm{ha}^{-1}\right)$} & \multicolumn{2}{|c|}{ Total S $\left(\mathrm{kg} \mathrm{ha}^{-1}\right)$} & \multicolumn{2}{|c|}{ Total Ca $\left(\mathrm{kg} \mathrm{ha}^{-1}\right)$} \\
\hline & AFD & $\mathrm{CF}$ & AFD & $\mathrm{CF}$ & AFD & $\mathrm{CF}$ & AFD & $\mathrm{CF}$ & AFD & $\mathrm{CF}$ \\
\hline 0 & $150.1^{\mathrm{a}}$ & $89.4^{\mathrm{b}}$ & $41.8^{\mathrm{a}}$ & $39.6^{\mathrm{a}}$ & $46.9^{\mathrm{a}}$ & $42.6^{\mathrm{a}}$ & $10.8^{\mathrm{a}}$ & $9.4^{\mathrm{a}}$ & $7.0^{\mathrm{a}}$ & $6.6^{\mathrm{a}}$ \\
\hline 3 & $145.6^{\mathrm{a}}$ & $76.9^{\mathrm{b}}$ & $43.7^{\mathrm{a}}$ & $37.1^{\mathrm{a}}$ & $46.5^{\mathrm{a}}$ & $39.7^{\mathrm{a}}$ & $10.8^{\mathrm{a}}$ & $9.6^{\mathrm{a}}$ & $6.4^{\mathrm{a}}$ & $5.9^{\mathrm{a}}$ \\
\hline 6 & $148.7^{\mathrm{a}}$ & $92.2^{\mathrm{b}}$ & $44.4^{\mathrm{a}}$ & $43.2^{\mathrm{a}}$ & $51.5^{\mathrm{a}}$ & $44.9^{\mathrm{a}}$ & $10.0^{\mathrm{a}}$ & $9.4^{\mathrm{a}}$ & $6.2^{\mathrm{a}}$ & $6.6^{\mathrm{a}}$ \\
\hline 12 & $148.6^{\mathrm{a}}$ & $114.7^{\mathrm{a}}$ & $44.9^{\mathrm{a}}$ & $43.9^{\mathrm{a}}$ & $49.1^{\mathrm{a}}$ & $44.6^{\mathrm{a}}$ & $9.8^{\mathrm{a}}$ & $10.0^{\mathrm{a}}$ & $6.5^{\mathrm{a}}$ & $7.0^{\mathrm{a}}$ \\
\hline 24 & $151.3^{\mathrm{a}}$ & $129.4^{\mathrm{a}}$ & $41.5^{\mathrm{a}}$ & $43.7^{\mathrm{a}}$ & $49.6^{\mathrm{a}}$ & $48.1^{\mathrm{a}}$ & $10.4^{\mathrm{a}}$ & $10.6^{\mathrm{a}}$ & $7.1^{\mathrm{a}}$ & $6.6^{\mathrm{a}}$ \\
\hline Water mean & 148.9 & 100.5 & 43.3 & 41.5 & 48.7 & 44.0 & 10.4 & 9.8 & 6.6 & 6.5 \\
\hline $\mathrm{CV} / \mathrm{F}$-test & Water & $17.4 * *$ & & $18.9 \mathrm{~ns}$ & & $24.1 \mathrm{~ns}$ & & $10.5 \mathrm{~ns}$ & & $20.2 \mathrm{~ns}$ \\
\hline CV/F-test & Rice straw & $9.1 * *$ & & $18.0 \mathrm{~ns}$ & & $19.2 \mathrm{~ns}$ & & $6.2 \mathrm{~ns}$ & & $22.6 n s$ \\
\hline
\end{tabular}

Average of four replications. In each column, means followed by a common letter are not significantly different at the 5\% level; ns $=$ not significant, $*$ = significant at $5 \%$ level, $* *=$ significant at $1 \%$ level.

was slightly greater than in the continuously flooded treatment but was not statistically different. Rice straw application rate had no significant effect on grain $\mathrm{P}$ uptake for either water management treatment. Trends in grain $\mathrm{K}, \mathrm{Ca}$ and $\mathrm{S}$ uptake were similar to grain $\mathrm{P}$ uptake. Grain $\mathrm{S}$ uptake in the continuously flooded treatment increased with an increasing rate of straw application but was not statistically different among treatments.

\subsection{Methane emission}

Methane was first detected during the second week (3 May 03 or 17 days after planting) in both the alternately flooded and drained (38.6 kg ha ${ }^{-1} \mathrm{~d}^{-1}$ ) treatment (Fig. 6) and the continuously flooded (34.9 kg ha-1 $\mathrm{d}^{-1}$ ) treatment (Fig. 7). Methane emissions continued to rise and peak methane emission from the alternately flooded and drained treatment $\left(85.6 \mathrm{~kg} \mathrm{ha}^{-1} \mathrm{~d}^{-1}\right)$ occurred four weeks after planting (19 May 03), and from the continuously flooded treatment $\left(225.1 \mathrm{~kg} \mathrm{ha}^{-1} \mathrm{~d}^{-1}\right)$ it occurred six weeks after planting (26 May 03). After that period, methane emission decreased with time, and for rice straw application of 12 and $24 \mathrm{t} \mathrm{ha}^{-1}$ a slight increase was again observed after the plots were drained just prior to harvest time. The lowest rate of methane emission was detected from the control treatment (no rice straw added) throughout the growing season. Methane

\section{Methane (kg/ha/d)}

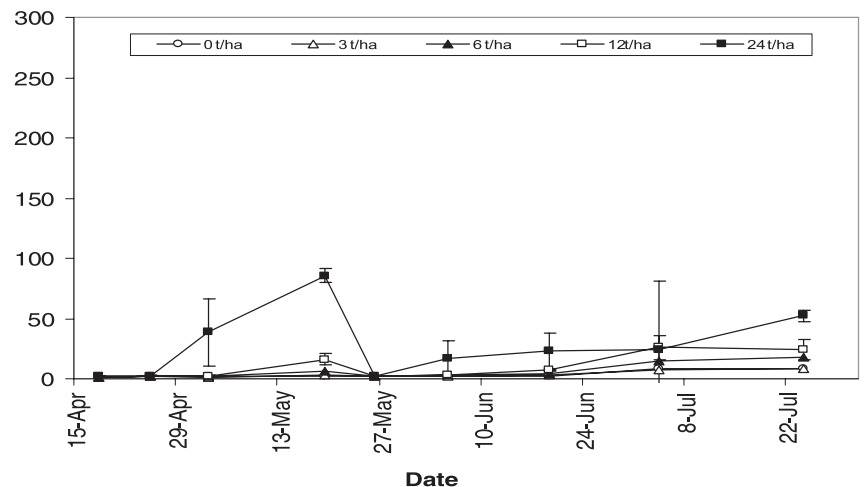

Figure 6. Effect of rice straw on methane emission from alternately flooded and drained treatment plots. 0 (control), 3, 6, 12 and $24 \mathrm{tha}^{-1}$ $=$ rice straw incorporation rates.

emission increased at high rates of rice straw addition for both water management treatments.

Methane emission at the highest rate of straw application $\left(24 \mathrm{t} \mathrm{ha}^{-1}\right)$ was remarkably greater compared with the other treatments. After draining (during 19-29 May 03), methane 


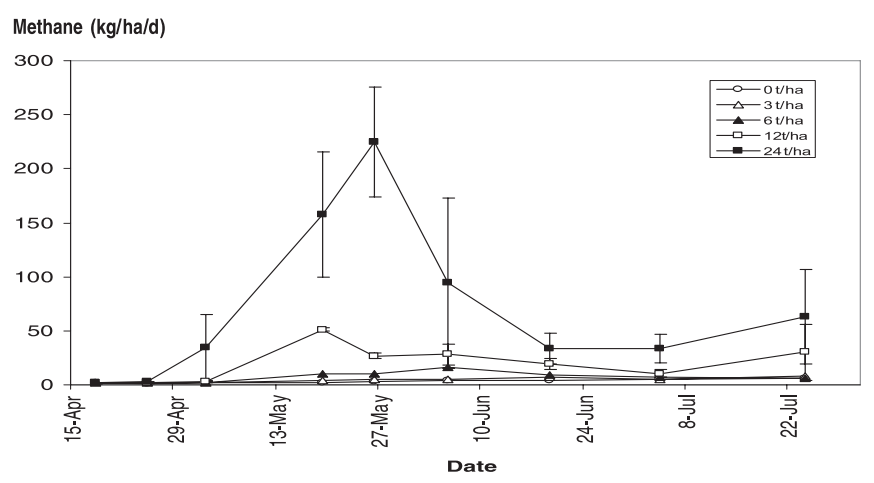

Figure 7. Effect of rice straw on methane emission from continuously flooded treatment plots. 0 (control), 3, 6, 12 and $24 \mathrm{tha}^{-1}=$ rice straw incorporation rates.

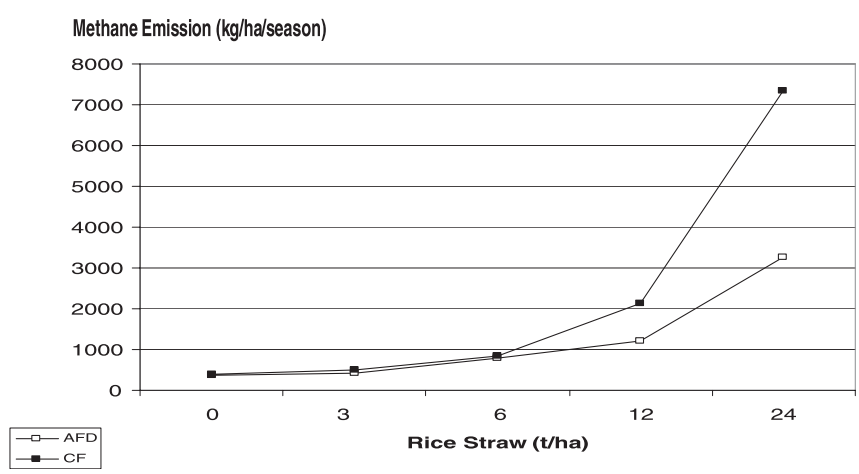

Figure 8. Effect of rice straw on methane emission per season of main crop (data were calculated by integrating the area under the line charts). AFD = alternately flooded and drained treatment, $\mathrm{CF}=$ continuously flooded treatment.

emission decreased considerably in all rice straw application treatments. Lu et al. (2000), Wang et al. (1992) and Wassmann et al. (2000) also reported that temporary midseason aeration in Asian rice soil reduced methane emission significantly. After reflooding, plots receiving the highest rate of straw application $\left(24 \mathrm{t} \mathrm{ha}^{-1}\right.$ ) again produced the highest methane emission throughout the remainder of the growing season. Rice straw incorporation during the land preparation stage increased methane emission during the early growth stage until 30 days after transplanting (Wassmann et al., 2000).

Methane emission over the entire growing season in treatments with the higher rice straw additions (12 and $24 \mathrm{t} \mathrm{ha}^{-1}$ ) were significantly greater compared with the lower straw application rates (Fig. 8). Neue et al. (1990) reported a similar increase in methane emission associated with an increase in soil organic matter. At low rates of straw application $(0,3$ and $\left.6 \mathrm{tha}^{-1}\right)$, total methane emission was less than $1000 \mathrm{~kg} \mathrm{ha}^{-1}$ over the growing season. Methane emission from the continuously flooded treatment was notably greater than that from the alternately flooded and drained treatment plots. Methane flux was reduced after midseason drainage due to aeration (Wassmann et al., 2000). The greatest emission rates were measured with the highest rice straw application rates $\left(12\right.$ and $\left.24 \mathrm{tha}^{-1}\right)$. Meth-

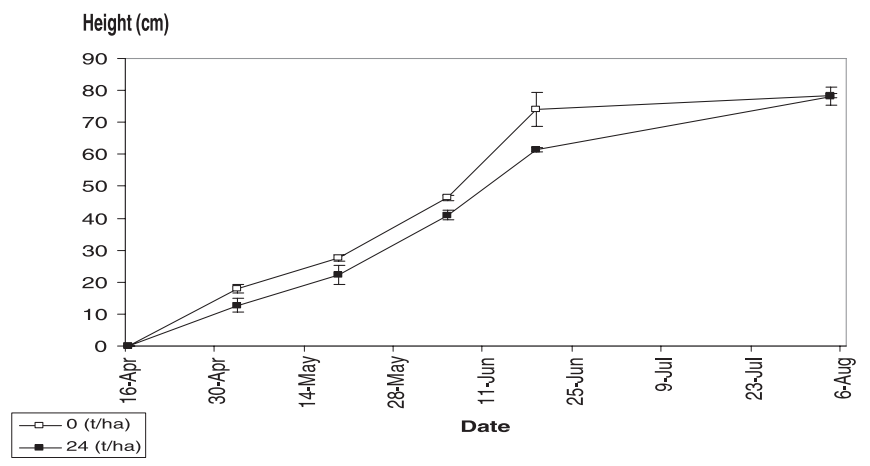

Figure 9. Effect of rice straw on plant height $(\mathrm{cm})$ in the alternately flooded and drained treatment (AFD); 0 and $24=$ rice straw incorporation rates $\left(\mathrm{t} \mathrm{ha}^{-1}\right)$.

ane emission from the alternately flooded and drained treatments with rice straw applications of 0,3 and $6 \mathrm{tha}^{-1}$ was slightly lower than the same rice straw additions for the continuously flooded treatments. Rice straw application increased methane emission because of methane produced from volatile fatty acids that were generated from rice straw decomposition (Wassmann et al., 2000).

\subsection{Plant growth}

Plant growth as influenced by the rice straw incorporation rate was observed at the early rice growth stage (1-3 weeks). Following drainage, plants in the alternately flooded and drained treatments were greener in color and more growth was observed than in the continuously flooded treatments. Number of plant tillers per unit area in each plot can be an important parameter in determining whether the plant was under stress from any adverse effect from rice straw addition. Plant tiller numbers observed for 5 different growth stages (17, 33, 50, 64 and 110 days after planting) showed no difference among the plots at each observing stage. Plant tiller numbers ranged between 316 and 440 tiller $\mathrm{m}^{-2}$ in the alternately flooded and drained treatment, and 281 to 411 tiller $\mathrm{m}^{-2}$ in the continuously flooded treatment, but the numbers were not correlated with the rates of rice straw addition. Tiller numbers in the alternately flooded and drained treatment were considerably greater than in the continuously flooded treatment. The enhanced growth of the rice plants in the alternately flooded and drained treatment was attributed to better root growth, which increased nutrient uptake and provided more oxygen to the root zone (Kirk and Solivas, 1997).

Plant height was also used for evaluating the impact of rice straw on rice growth. Plant heights at the three low rates of straw application (0,3 and $\left.6 \mathrm{tha}^{-1}\right)$ after the draining period (1929 May 03) in the alternately flooded and drained treatments were remarkably greater than the continuously flooded treatment (Fig. 9). At the high rates of rice straw application (12 and $\left.24 \mathrm{tha}^{-1}\right)$, plant height in both water management treatments was not different (Fig. 10). Average plant heights in the alternately flooded and drained and the continuously flooded treatments were similar $(16$ and $16 \mathrm{~cm}$ ) for the first sampling (17 days after planting), and the second sampling (33 days after 


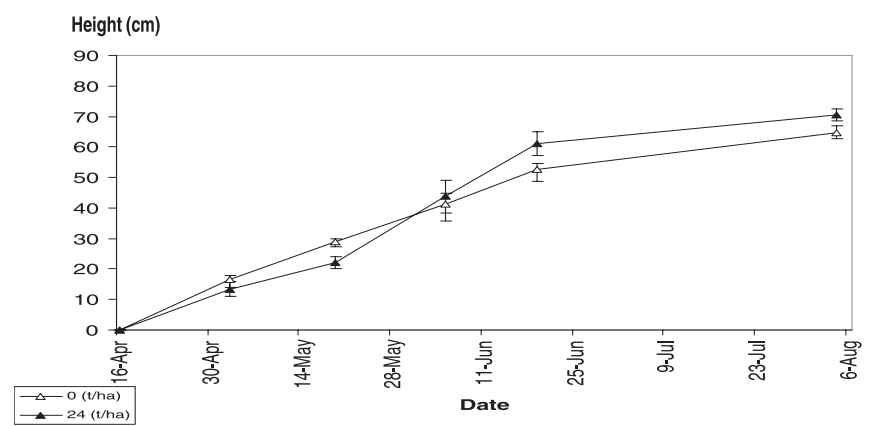

Figure 10. Effect of rice straw on plant height $(\mathrm{cm})$ in the continuously flooded treatment $(\mathrm{CF}) ; 0$ and $24=$ rice straw incorporation rates $\left(\mathrm{tha}^{-1}\right)$.

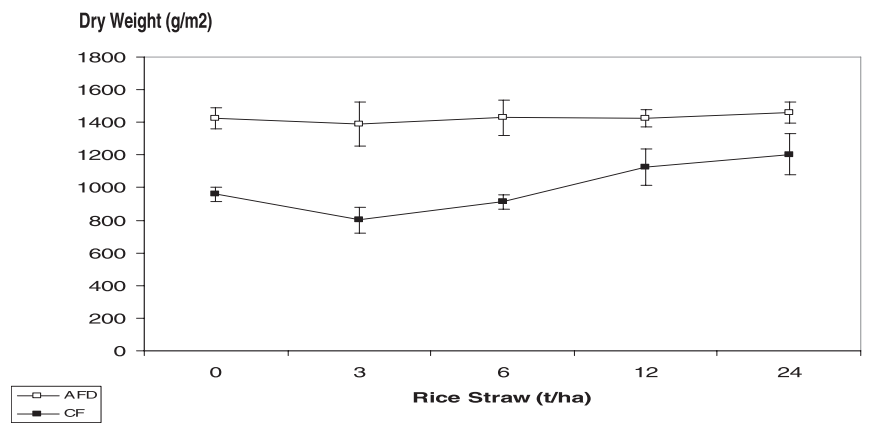

Figure 11. Effect of rice straw and water management practices on dry matter weight; AFD = alternately flooded and drained treatment, $\mathrm{CF}=$ continuously flooded treatment. Statistical tests: $\mathrm{AFD}=\mathrm{ns}$; $\mathrm{CF}=*$.

planting) was 27 and $26 \mathrm{~cm}$. However, following drainage, plant height in the alternately flooded and drained treatment was significantly greater $(P<0.05)$ compared with the continuously flooded treatment. The average height at harvest in the continuously flooded treatment was $65 \mathrm{~cm}$ and it was $79 \mathrm{~cm}$ in the alternately flooded and drained treatment (with rice straw application of $0-24 \mathrm{tha}^{-1}$ ).

\subsection{Plant dry matter and grain yield}

Dry matter weight with the higher rice straw application rates was significantly greater $(P<0.05)$ compared with the lower rice straw application rates in the continuously flooded treatment (Fig. 11). There were no significant differences of dry weight in the alternately flooded and drained treatment. The control treatment in the continuously flooded plots had similar dry matter yield to the treatment yield with rice straw applications at 3 and $6 \mathrm{t} \mathrm{ha}^{-1}$. This occurrence might have been due to the rice straw having an adverse effect on the growth of the rice in the continuously flooded treatment compared with the alternately flooded and drained treatment. Rice straw application rate did not show any relationship to plant dry matter in the alternately flooded and drained treatment, but there was a significant difference $(P<0.05)$ in plant dry matter for the con-



Figure 12. Effect of rice straw and water management practices on grain weight; $\mathrm{AFD}=$ alternately flooded and drained treatment, $\mathrm{CF}=$ continuously flooded treatment. Statistical tests: $\mathrm{AFD}=\mathrm{ns} ; \mathrm{CF}=$ *.

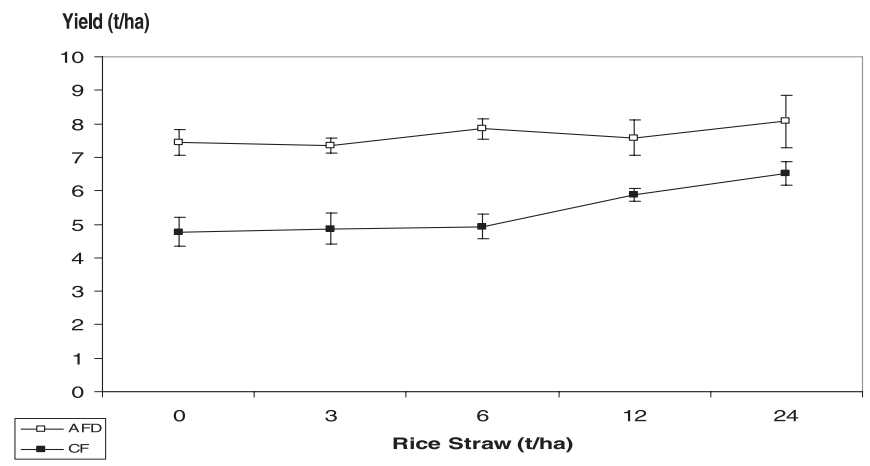

Figure 13. Effect of rice straw and water management practices on grain yield (harvest from whole plot); $\mathrm{AFD}=$ alternately flooded and drained treatment, $\mathrm{CF}=$ continuously flooded treatment. Statistical tests: $\mathrm{AFD}=\mathrm{ns} ; \mathrm{CF}=*$.

tinuously flooded treatment. Dry matter weight in the alternately flooded and drained treatment was significantly greater than the continuously flooded treatment $(P<0.01)$.

Grain weight collected from $0.5-\mathrm{m}^{2}$ subplots showed significant differences among both rice straw applications and water management treatments (Fig. 12). In the continuously flooded treatment, the trend was similar to plant dry matter weight, except grain weight decreased in the $24 \mathrm{t} \mathrm{ha}^{-1}$ rice straw treatment. In the alternately flooded and drained treatment, grain weight did not show any significant difference at increasing rates of straw application. The alternately flooded and drained treatment had significantly increased grain weight compared with the continuously flooded treatment.

Whole plot $\left(12.6 \mathrm{~m}^{2}\right)$ grain yield from the continuously flooded treatment increased at high rates of rice straw application (12 to $24 \mathrm{t} \mathrm{ha}^{-1}$ ) (Fig. 13). Grain yield in the alternately flooded and drained did not significantly increase at high rates of rice straw. The alternately flooded and drained treatment resulted in greater grain yield compared with the continuously flooded treatment at all levels of straw application. These findings are in agreement with Wassmann et al. (2000) who reported that alternate flooding/drying at midseason could increase rice production as compared with continuous flooding. 


\section{CONCLUSION}

Methane emission (a greenhouse gas associated with global warming) increased in this study with amount of straw addition under both water management practices. The results of this study clearly demonstrate that draining Louisiana rice fields for a short period of time during the growing season can both enhance rice growth and yield, and reduce methane emission to the atmosphere. This research is in agreement with other studies (Wassmann et al., 2000; Lu et al., 2000) which reported that methane emission from paddy rice fields in China, India, Indonesia, Thailand and the Philippines could be reduced by up to $60 \%$ by drainage during the growing season with no significant impact on rice yield. Temporary soil alteration, however, could result in greater $\mathrm{N}_{2} \mathrm{O}$ emission. (Bronson et al., $1997 \mathrm{a}, \mathrm{b})$. Further studies of the water management strategies in Louisiana rice fields will need to quantify the impact of water management strategies on $\mathrm{N}_{2} \mathrm{O}$ emission (another significant greenhouse gas).

\section{REFERENCES}

Bray R.H., Kurtz L.T. (1945) Determination of total, organic and available forms of phosphorus in soils, Soil Sci. 59, 39-45.

Bronson K.F., Neue H.U., Singh U., Abao E.B. Jr. (1997a) Automated chamber measurement of methane and nitrous flux in a flooded rice soil. I. Effect of organic amendments, nitrogen source, and water management, Soil Sci. Soc. Am. 61, 981-987.

Bronson K.F., Neue H.U., Singh U., Abao E.B. Jr. (1997b) Automated chamber measurement of $\mathrm{CH}_{4}$ and $\mathrm{N}_{2} \mathrm{O}$ flux in a flooded rice soil. II. Fallow period emissions, Soil Sci. Soc. Am. 61, 988-993.

Cho D.Y., Ponnamperuma F.N. (1971) Influence of soil temperature on the chemicals kinetics of flooded soils and the growth of rice, Soil Sci. 112, 184-194.

Gao S., Tanji K.K., Scardaci S.C. (2004) Impact of rice straw incorporation on soil redox status and sulfide toxicity, Agron. J. 96,70-76.

Hill J.E., Roberts S.R., Brandon D.M., Scardaci S.C., Williams J.F., Wick C.W., Canevari W.M., Weir B.L. (1992) Rice Production in California, Coop. Ext. Univ. Calif. Div. Agric. Nat. Res. Publ. 21498.

Holzapfel-Pschorn A., Conrad R., Sieler W. (1986) Effects of vegetation on the emission of methane from submerged paddy soil, Plant Soil 92, 223-233.

IRRI (1992) IRRISTAT User's manual, Version 92-1, International Rice Research Institute, Los Banos, Philippines.

IRRI (2000) International Rice Research Institute, Methane emission from rice fields, http://riceweb.org/research/Res_issmethane.htm.

IRRI (2002) World Rice Statistics, International Rice Research Institute, http://www.irri.org/science/ricestat/index.asp (Accessed June 16, 2005).

Kirk G.J.D., Solivas J.L. (1997) On the extent to which root properties and transport through the soil limit nitrogen uptake by lowland rice, Eur. J. Soil Sci. 48, 613-621.

Kludze H.K., DeLaune R.D. (1995) Straw application effects on methane and oxygen exchange and growth in rice, Soil Sci. Soc. Am. J. 59, 824-830.

Lindau C.W., Bollich P.K., DeLaune R.D., Patrick W.H. Jr., Law V.J. (1991) Effects of urea fertilizer and environmental factors on methane emissions from Louisiana, USA rice field, Plant Soil 136, 195-203.
Lindau C.W., Bollich P.K., DeLaune R.D., Mosier A.R., Bronson K.F. (1993) Methane mitigation in flooded Louisiana rice field, Biol. Fertil. Soils 15, 174-178.

Lindsay W.L., Norvell W.A. (1978) Development of a DTPA test for zinc, iron, manganese, and copper, Soil Sci. Soc. Am. J. 42, 421428.

Linscombe S.D., Saichuk J.K., Seilhan K.P., Bollich P.K., Funderburg E.R. (1999) General agronomic guidelines, in: Louisiana Rice Production Handbook, LSU Agric. Ctr. Publ. 2321, pp. 5-12.

Lu W.F., Chen W., Duan B.W., Guo W.M., Lu Y., Lantin R.S., Wassmann R., Neue H.U. (2000) Methane Emissions and Mitigation Options in Irrigated Rice Fields in Southeast China, Nutr. Cycl. Agroecosyst. 58, 65-73.

McLean E.O. (1982) Soil pH and lime requirement, in: Methods of soil analysis, Part 2. Chemical and microbiological properties. Agronomy Monograph No. 9 (2nd ed.), pp. 199-224.

Miller T.C., Street J.E. (1999) Mississippi Rice Grower Guide. Mississippi State University Cooperative Extension Service, Mississippi State, MS, USA.

Nelson D.W., Sommers L.E. (1982) Total carbon, organic carbon, and organic matter, in: Methods of soil analysis. Part 2. Chemical and microbiological properties, Agronomy Monograph No. 9 (2nd ed.), pp. 539-579.

Neue H.U. (1993) Methane emission from rice fields: Wetland rice fields may make a major contribution to global warming, BioScience 43, 466-473.

Neue H.U. (1997) Fluxes of methane from rice fields and potential for mitigation, Soil Use Manag. 13, 258-267.

Neue H.U., Becker-Heidmann P., Scharpenseel H.W. (1990) Organic matter dynamics, soil properties, and cultural practices in rice lands and their relationship to methane production, in: Bouwman A.F. (Ed.), Soil and the Greenhouse Effect, John Wiley, New York, pp. 457-466.

Neue H.U., Latin R.S., Wassmann R., Aduna J.B., Alberto C.R., Andales M.J.F. (1994) Methane emission from rice soils of the Philippines, in: Minami K., Mosier A., Sass R. (Eds.), $\mathrm{CH}_{4}$ and $\mathrm{N}_{2} \mathrm{O}$ : Global Emissions and Controls from Rice Fields and Other Agricultural and Industrial Sources, Yokendo Publishers, Tokyo, pp. 55-63.

Ponnamperuma F.N. (1984) Straw as source of nutrients for wetland rice, in: Organic matter and rice, Los Banos, Philippines, International Rice Research Institute, pp. 117-136.

Rolston D.E. (1986) Gas Flux, in: Methods of soil analysis. Part 1, 2nd ed., Klute A. (Ed.), Agronomy Monograph No. 9. ASA and SSSA, Madison, WI, pp. 1103-1119.

Sass R.L. (2003) $\mathrm{CH}_{4}$ Emissions from Rice Agriculture, IPCC Expert Meetings on Good Practice Guidance and Uncertainty Management in National Greenhouse Gas Inventories, pp. 399-417.

Sass R.L., Fisher F.M., Harcombe P.A., Turner F.T. (1990) Methane production and emission in agricultural wetlands, Global Biogeochem. Cy. 4, 47-68.

Sass R.L., Fisher F.M., Harcombe P.A., Turner F.T. (1991a) Mitigation of methane emissions from rice fields: Possible adverse effects of incorporation rice straw, Global Biogeochem. Cy. 5, 275-287.

Sass R.L., Fisher F.M., Turner F.T., Jund M.F. (1991b) Methane emission from rice fields as influenced by solar radiation, temperature, and straw incorporation, Global Biogeochem. Cy. 5, 335-350.

Sass R.L., Fisher F.M., Wang Y.B., Turner F.T., Jund M.F. (1992) Methane emission from rice fields: The effect of floodwater management, Global Biogeochem. Cy. 6, 249-262.

Sass R.L., Fisher F.M., Lewis S.T., Jund M.F., Turner F.T. (1994) Methane emission from rice fields: effect of soil properties, Global Biogeochem. Cy. 8, 135-140. 
Schutz H., Holzapfel-Pschorn A., Conrad R., Rennenberg H., Seiler W. (1989) A three-year continuous record on the influence of daytime season and fertilizer treatment on methane emission rates from an Italian rice paddy field, J. Geophys. Res. 94, 16405-16416.

Soil Survey Laboratory Methods Manual (1996) Soil survey investigations report No. 42, Soil Conservation Service, USDA, National Soil Survey Center, Version 3.0, January 1996.

Street J.E., Bollich P.K. (2003) Chapter 3.2, Rice Production, in: Smith C.W. (Ed.), Rice: Origin, History, Technology, and Production, John Wiley \& Sons, Inc, pp. 271-296.

Tabatabai M.A. (1982) Sulfur, in: Methods of soil analysis. Part 2. Chemical and microbiological properties, Agronomy Monograph No. 9 (2nd ed.), pp. 501-538.

Thomas G.W. (1982) Exchangeable cations, in: Methods of soil analysis. Part 2. Chemical and microbiological properties, Agronomy Monograph No. 9 (2nd ed.), pp. 159-165.

Wang Z., DeLaune R.D., Lindau C.W., Patrick W.H. Jr. (1992) Methane production from anaerobic soil amended with rice straw and nitrogen fertilizers, Fert. Res. 33, 115-121.
Wassmann R., Neue H.U., Lantin R.S., Makarim K., Chareonsilp N., Buendia L.V., Rennenberg H. (2000) Characterization of methane emissions from rice fields in Asia. II. Differences among irrigated, rainfed and deepwater rice, Nutr. Cycl. Agroecosyst. 58, 13-22.

Wassmann R., Lantin R.S., Neue H.-U., Buendia L.V., Corton T.M., Lu Y. (2000) Characterization of Methane Emissions from Rice Fields in Asia. III. Mitigation Options and Future Research Needs, Nutr. Cycl. Agroecosyst. 58, 23-36; Emission in agricultural wetlands, Global Biogeochem. Cy. 4, 47-68.

Wassmann R., Wang M.X., Shangguan X.J., Xie X.L., Shen R.X., Papen H., Rennenberg H., Seiler W. (1993) First records of a field experiment on fertilizer effects on methane emission from rice fields in Hunan Province (PR China), Geophys. Res. Lett. 20, 2071-2074.

Whiting G.J., Chanton J.P., Bartlett D.S., Happel J.D. (1991) Relationships between $\mathrm{CH}_{4}$ emissions, biomass, and $\mathrm{CO}_{2}$ exchange in a subtropical grassland, J. Geophys. Res. 96, 13067-13071.

Yagi K., Tsuruta H., Kanda K., Minami K. (1996) Effect of water management on methane emission from a Japanese rice paddy field: Automated methane monitoring, Global Biogeochem. Cy. 10, $255-267$. 